\title{
THE SIXTH ANNUAL MEETING, 1977
}

The Sixth Annual Meeting was held in London on 5, 6 and 7 July 1977 under the Presidency of Professor W. LINFORd REEs.

\section{Scientific Meetings}

The meetings on Tuesday 5 July were held at the Royal Free Hospital.

In the morning Professor W. Linford Rees chaired sessions on Anorexia Neroosa and Compulsory Admissions to Hospital, at which the following papers were read: 'Faulty Mechanisms underlying Amenorrhoea in Anorexia Nervosa', Dr Anthony Wakeling; 'SelfInduced Vomiting: a Variant of Anorexia Nervosa', Professor Gerald Russell; 'Methods of Behaviour Therapy', Dr Peter Slade; 'How Anorexia Patients See Themselves', Mr Eric Button; and 'The Glinical and Social Aspect of Compulsory Admissions', Dr George Szmukler and Dr Patrick Campbell.

In the afternoon there were parallel sessions.

Professor Rees chaired the session on Medical Responsibility, which was introduced by Dr A. Glare; papers were read as follows: 'The Changing Face of Medical Responsibility', Dr M. Green, Consultant Physician, Royal Free Hospital, Member of GMC; 'Medical Responsibility: Does the Law Help or Hinder?', Mr Charles Butcher, Solicitor to the Medical Defence Union.

Dr W. A. Heaton-Ward chaired the second session, at which the following papers were read: 'Short-term Psychotherapy with Compulsive Patients', Dr James F. Suess, Visiting Professor, University of Mississippi ; 'Personal Construct Psychotherapy', Dr Fay Fransella; 'Sex Roles in Psychiatric Disorders', Miss K. Frost; 'The Teaching of Liaison Psychiatry to Medical Students', Dr Michael Simpson; 'Limitations in Doctor-Patient Contact in Mental Hospital Practice', Dr Howard Sergeant, Dr David Pitcher.

The Distinguished Guest Lecture on 6 July was delivered by Professor Jose Delgado and was entitled 'Psychiatric Implications of Brain Inhibition'; the vote of thanks was proposed by Dr G. C. Timbury.

On 7 July there were parallel sessions in the morning as follows: Social and Community Psychiatry, Chairman Professor Linford Rees; 'The Use of Psychiatric Resources for Indirect Service', Dr G. M. Parkes; 'Community Psychiatric Services', Dr D. H. Bennett; 'Models of Community Psychiatry', Dr J. A. Corbett; 'Confidentiality', Dr J. Leff.

Dr Peter Sainsbury, Vice-President, was in the
Chair for the following sessions: Does it Work? Papers: 'Is ECT Effective? Preliminary Results from a Controlled Trial', Dr J. Lambourn; 'A Controlled Study of the Effect of the Samaritans on the Suicide Rate of England and Wales: Negative Findings', Drs C. Jennings, B. Barraclough, J. Moss; 'Crisis Intervention after Deliberate Self Poisoning: a Trial of Task Centred Social Work', Professor J. Gibbons.

Transmitters in Dementia, 'Cholinergic Mechanisms in Alzheimer's Disease', Dr P. Davies; 'Cholinergic and GABA Systems in Dementia and Old Age', Drs E. Perry, R. Perry; 'Selective Changes in Transmitter Systems in Post Mortem and Biopsy Brain Tissue', Drs D. M. Bowen, A. N. Davison.

In the afternoon Professor Rees and Dr Sainsbury chaired the further parallel sessions:

A. 'Prediction of Response to Treatment in Depressives', Professor M. Hamilton; 'Acute Psychotic Reactions in Migrants', Drs Roland Littlewood and Maurice Lipsedge; 'The Incidence of Post-Abortion Psychosis and its Implications for the Aetiology and Treatment of Puerperal Psychosis', Dr Colin Brewer; 'The Clinical Study of Postpartum Psychosis', Drs Ian F. Brockington and Clive Hyde; 'Psychiatric Disturbance in Pregnancy and the Puerperium', Dr R. Kumar.

B. 'How Special are the Special Hospitals?', Dr T. G. Tennent; 'Gender Identity Disorders: Social, Interpersonal and Personality Aspects', Dr J. M. Annear; 'Determinants of Prolonged Hospitalization', Dr Isam E. Babiker; 'The EEG in Antisocial Behaviour: A Study of Borstal Boys', Professor G. W. Fenton; 'Should Psychiatrists Assess Patients with Self-Poisoning in the General Hospital?', Dr R. Gardner.

On Monday 4 July the Forensic Psychiatry Section organized a conference on The Research Aspects of Regional Secure Units. The Chairman of the Section, Dr Peter Scott, took the Chair and papers were presented by Dr Paul Bowden, 'Locked Wards and Violent Offenders'; Dr John Orley, 'Follow-up of the Subjects Identified in the Oxford Survey (Regional Security Unit Needs)'; Mrs Moya Woodside and Dr John Basson, 'The First Two Years' Experience of a Medium-Security Ward'.

At the meeting of the Psychotherapy Section (Chairman: Dr R. Gosling), Dr J. Hafner and Dr S. Lieberman presented a paper entitled 'The Peripatetic Teaching of Psychotherapy: The Development of a Regional Programme in Psychotherapy'. 


\section{The General Meeting}

The President, Professor W. LINFord ReEs, in the Chair.

The Minutes of the previous meeting held in London on 6, 7 and 8 July 1976, having been published in the Bulletin (July 1977) were approved as a correct record and signed.

\section{Obituary}

The Registrar, Dr MorRis Markowe, announced with regret the death of the following members:

Patriak Joseph Gassin, formerly Medical Superintendent, Kilkenny Mental Hospital (Chairman, Irish Division, 1948-50).

Yoall Mrir Ghaikin, Consultant Psychiatrist, Whittington Hall, Chesterfield.

Geare RUTH Donger, formerly Psychiatrist, Berkshire Ghild Guidance Service.

Magnus Ross Mackay, M.C., formerly Medical Superintendent, Newport Borough Mental Hospital (St. Cadoc's), Caerleon.

Nicholas Borrell Malleson, Director, Research Unit for Student Problems, University of London.

Bernard Weston March, formerly Superintendent, New Hampshire Hospital, Concord, New Hampshire, USA.

Drsmond Francis David O’Neill, M.C., Physician, Department of Psychological Medicine, Queen Charlotte's Hospital and Chelsea Hospital for Women, London.

William Walter Roberts, formerly Consultant Psychiatrist, Saxondale Hospital, Notts.

James Harvey Strachan Whyte, Consultant Psychiatrist, Middlewood Hospital, Sheffield.

Zoltan Wisinger, O.B.E., Medical Superintendent, Mental Hospital, St John's, Antigua, West Indies.

\section{Annual Report of Council}

Frve AND TWENTY-FIve

This is our fifth Annual Report, and as we look back on five years of growth and expansion as a Royal College we also celebrate the Jubilee of the Accession to the Throne of Her Majesty Queen Elizabeth. Earlier this year we sent to Her Majesty the following Loyal Address:

To the Queen's Most Excellent Majesty May it please Your Majesty:

We, your Majesty's dutiful and faithful subjects, the President, Council and members of THE ROYAL COLLEGE OF PSYCHIATRISTS most respectfully desire to approach Your Majesty with the expression of loyal and hearty congratu- lations upon the occasion of the Twenty-Fifth Anniversary of your Succession.

All our members pray that Your Majesty may long be spared to reign over them in health and happiness and that the blessings of peace and prosperity may ever attend your Reign.

Given under our seal

$\begin{array}{ll}\text { W. LINFORD REES } & \text { President } \\ \text { WILFRD WARREN } & \text { Treasurer } \\ \text { MORRIS MARROWE } & \text { Registrar } \\ \text { KENNETH RAWNSLEY } & \text { Dean }\end{array}$

The following reply has been received:

Home Office

London

26 May 1977

Sir

I have had the honour to lay before The Queen the Loyal and Dutiful Address of the President, Council and members of the Royal College of Psychiatrists on the occasion of Her Majesty's Silver Jubilee and I have it in Command from The Queen to convey Her Majesty's warm thanks for the assurances of loyalty and affection contained in the Address.

Her Majesty was graciously pleased to remark upon the artistic merit of the Address.

$$
\text { I am, }
$$$$
\text { Sir, }
$$

Your obedient Servant signed M. Rees

The President

Royal College of Psychiatrists

FIFTY

The year 1976 marked the 5oth anniversary of the granting of a Royal Charter to what was then the 'Medico-Psychological Association', the further grant of a coat of arms, and the assumption of our motto 'Let Wisdom Guide', which it has now been decided shall remain the motto of the College. Our first meeting as a Royal Association has been recalled in an article in News and Notes (November 1976), and this may remind us also of another anniversary referred to modestly by the author, Dr Alexander Walk, for it was in that same year that he was elected a member of the Association. In May 1928, he was appointed Assistant Editor of the Fournal, and next year there will be a celebration of his 50 years of continuous service to the Association and the College.

\section{Council}

Throughout the year Council has received, 
considered and approved many documents prepared by its Executive and Finance Committee, the Standing Committees and the Special Committees set up to deal with particular items. The Council is widely representative of our members in the Divisions and in the Specialties and receives reports of College activities throughout Great Britain and Ireland. Much of the work of the College is reported regularly in The Bulletin of the Royal College of Psychiatrists (formerly News and Notes), through the Registrar's Reports to Quarterly Meetings, and through individual contributions, as well as the publication of memoranda which have been approved by Council. This Annual Report reviews some of the main events of the year which have often been more fully reported elsewhere.

The following Officers took office at the Annual Meeting in 1976 :

\begin{tabular}{|c|c|}
\hline $\begin{array}{l}\text { President } \\
\text { Registrar } \\
\text { Treasurer } \\
\text { Dean } \\
\text { Editor } \\
\text { Librarian } \\
\text { Sub-Deans }\end{array}$ & $\begin{array}{l}\text { Professor W. LINFORd REES } \\
\text { Dr MorRIS MARKOWE } \\
\text { Dr WILFRID WARREN } \\
\text { Professor K. RAWNSLEY } \\
\text { Dr E. H. HARE } \\
\text { Dr H. R. RolLIN } \\
\text { Dr T. H. BeWLEY } \\
\text { Dr C. P. B. BROOK } \\
\text { Dr A. SHAPIRO }\end{array}$ \\
\hline
\end{tabular}

Dr Peter Sainsbury entered his second year as Vice-President, and at the Council Meeting in October $1976 \mathrm{Dr}$ W. A. Heaton-Ward was elected as the other Vice-President.

Council nominations for Officers for $1977-1978$ were made, in accordance with the Bye-Laws, in January and March and at the time of going to press with this Report ballots are being held for the offices of Dean and Sub-Deans. Dr E. H. Hare did not stand for re-election as Editor; one nomination was received, and Dr Hare will be succeeded by Dr J. L. Crammer in July. The other Officers will continue to serve for a further year. It should be noted that neither the President, Professor Linford Rees, nor the Registrar, Dr Markowe, will be eligible for re-election in 1978; other Officers will be eligible for re-election as follows: Treasurer, Dr Warren-I year; Librarian, Dr Rollin-8 years; Sub-Dean, Dr C. P. B. Brook (if re-elected in 1977) -2 years.

At last year's Annual Meeting recommendations submitted by Council for changes in the Bye-Laws to allow for more formal representation of trainees were approved, and these are now before the Privy Council; we had earlier submitted a petition to revise the Bye-Laws concerned with subscription rates, and these changes have been approved by the Privy Council.
Many matters of public interest have been of great concern to the College. A Special Committee under the Chairmanship of the President prepared evidence for the Royal Commission on the National Health Service (News and Notes, April 1977). Following Reports of Committees of Inquiry and a meeting with Dr David Owen (DHSS), a Special Committee under the Chairmanship of Professor A. K. M. Macrae prepared recommendations on the conduct of Committees of Inquiry (News and Notes, September 1976); following the Report on St Augustine's Hospital, and at the request of the Regional Health Authority and others, a Special Committee, chaired by Dr Peter Sainsbury, prepared a memorandum on the Use and Administration of ECT (to be published).*

In response to strong action taken by the College and other medical bodies (News and Notes, February 1977) the Secretary of State set up a Section 70 Inquiry under the NHS Act to investigate events leading up to the suspension of a member by his employing authority; the College was invited to nominate the psychiatric representative to serve on this Committee. Members of the College were also involved in an advisory capacity in the Inquiry set up by the Scottish Home and Health Department (Section 108 of the Mental Health Act, Scotland) into the State Hospital at Carstairs. The Report of neither Committee is available at the time of going to press.

For some time the College has been pressed to make a statement on the responsibilities of Consultants. A Special Committee under the Chairmanship of Dr Brian Ward prepared a draft document which was submitted to the Executive and Finance Committee and to the Council. This was rewritten in the light of comments invited and received from members of these bodies and the memorandum on The Responsibilities of Consultant Psychiatrists in the National Health Service has now been approved and widely distributed and will be published in the Bulletin. The College memorandum does not claim to be comprehensive but is intended to provide broad guidelines. It emphasizes the fact that the responsibilities of Consultants in Psychiatry are the same as those of any other Consultants in the Health Service; the Consultant represents ultimate medical authority for the patients in his care. He has, by virtue of professional qualification, Acts of Parliament, and his contract, the authority and responsibility to diagnose and prescribe treatment and this responsibility cannot be wholly devolved elsewhere. In the hospital service the Consultant associates with a

- Published in the British Journal of Psychiatry, September 1977, 131, 261 . 
variety of other disciplines of widely differing professional status; in the multi-disciplinary team communication at all levels and a team spirit are important for patient care; varying multi-disciplinary models may best suit varying situations, and communication, consultation and co-operation may be achieved in varying ways.

The College's concern about human rights continues. The further Resolution about the abuse of psychiatry, passed by the Quarterly Meeting in May, 1976 and reported to last year's Annual Meeting has been accepted as an item for the Agenda of the meeting of the General Assembly of the World Psychiatric Association in Hawaii in August; Dr Peter Sainsbury, Vice-President, will represent the College at this meeting. Plans for a joint commission of inquiry with the legal profession to visit the Soviet Union in order to investigate allegations of the abuse of psychiatry had to be abandoned because of the non-co-operation of the Soviet authorities (News and Notes, December 1976). Council's good wishes were conveyed by the President to Mr Vladimir Bukovsky on his arrival in Britain. The College is currently trying to ascertain facts about the fate of psychiatrists and psychologists in Argentina.

Following the publication of the Report of the European Commission on Human Rights on the Investigation of Interrogation Procedures used by the British Army in Northern Ireland in 1971 , the College issued a statement condemning these procedures and confirming its support of any member refusing to be associated with such practices.

\section{Special Comomtreses}

Much of the work of the Council which cannot easily be undertaken by the Standing Committees, or which overlaps with other bodies within the College, is referred to Special Committees representative of the appropriate Standing Committee(s), Specialist Section(s) and/or Division(s). In addition to items referred to elsewhere in this Report, Special Committees have prepared evidence for the Royal Commission on Gambling (Ghairman: Dr E. Moran) (News and Notes, May 1977); the House of Commons Select Committee on Violence in the Family (Chairman: Dr Peter Scott) (British Fournal of Psychiatry, 1977); the Report of the Sub-Committee (Trethowan) of the Standing Mental Health Advisory Committee on the Role of Psychologists in the Health Services (Chairman: Professor Max Hamilton) (News and Notes, May 1977); the (Jay) Committee of Inquiry into Nursing Care for the Mentally Handicapped (Chairman: Dr W. A. Heaton-Ward) (Newes and Notes, March 1977); and comments have been submitted on the First Report of the Select Committee on Abortion and on Mr William Benyon's Abortion (Amendment) Bill (Chairman: Professor R. Priest).

Special Committees are currently preparing reports on Sick Doctors (Chairman: Professor K. Rawnsley); Child Health Services (Ghairmen: Mental Handicap; Professor W. Linford Rees; Child and Adolescent Psychiatry: Professor P. Graham); and the Special Committee on Alcoholism is considering a final draft of its report. The Special Committee on Mental Handicap, which was set up following the endorsement by Council of the Section's Statement (News and Notes, October 1976), has met on several occasions and hopes to present its report and recommendations to Council before the end of the year.

\section{Standing Commitrees}

The Education Committee (Chairman: Professor K. Rawnsley; Secretary: Dr T. H. Bewley) and its Sub-Committees and Working Parties (Clinical Tutors, Library and Reading Lists, Manpower, Nursing, Overseas Trainees, Trainees, and Women in Psychiatry) have undertaken a number of major projects during the year. Regular meetings between representatives of the DHSS and the Manpower Sub-Committee continue, and items discussed have included a memorandum on the Non-Consultant Non-Training Grades and on Manpower Priorities. The Clinical Tutors Sub-Committee is introducing a scheme for the recognition of psychiatric tutors and is sending an application form to all tutors known to the College. A List of Books for Psychiatric Libraries, prepared by the Library and Reading Lists SubCommittee, is being published. The Overseas Trainees and the Trainees Working Parties continue to be concerned with all matters affecting trainees; at the request of the College the Conference of Presidents of Royal Medical Colleges and Faculties is considering certain discriminatory aspects of EEC Directives in relation to overseas trainees, and it is hoped that the Conference will agree to recommend that all medical graduates who have completed the approved period of training in an EEC country should be considered for EEC Specialist Registration irrespective of their country of origin or of their undergraduate training. The Nursing Sub-Committee was represented on the Special Committee which prepared evidence for the Committee of Inquiry into Nursing and Gare of the Mentally Handicapped. The Working Party on Women in Psychiatry prepared comments on the Joint Consultants Committee circular on Women in Medicine, which were approved by the Executive and Finance Committee 
and submitted to the JCC; the Working Party is also considering the results of its survey of women in service grades.

The Public Policy Committee (Chairman: Dr W. A. L. Bowen; Secretary: Dr Brian Ward) has submitted a number of documents to Council, and its representatives have served on a number of Joint Committees and taken part in meetings at the Department of Health and Social Security. A Working Party prepared evidence for the (Brodrick) Committee on Death Certification and Coroners. The College's comments on 'A Review of the Mental Health Act' (News and Notes, January and March 1977), prepared by a Working Party of the Public Policy Committee, were adopted by the Joint Consultants Committee, who were subsequently represented by members of the College at a meeting with the Interdepartmental Committee. Members of the Committee also represented the College at a Conference on the Review organized by the DHSS. Comments on the DHSS Draft Code of Practice: Health Services Complaints Procedure were approved by Council. The Public Policy Committee has continued to keep a watching brief on matters of public interest and has commented upon the abuse of psychiatry, interrogation procedures, the closure of hospitals, the voting rights of psychiatric patients, Committees of Inquiry and many other matters of concern to psychiatrists, their patients and the public.

The Programmes and Meetings Committee (Chairman: Professor K. Rawnsley; Secretary: Dr C. M. B. Pare) has again organized a series of successful meetings throughout the year. Professor W. Linford Rees entered his second year as President at the Annual Meeting in July 1976; the Distinguished Guest Lecturer was Dr Nathan Kline, who spoke on 'Trends in American Psychiatry'. The first day of the Autumn Quarterly Meeting in 1976 was held at the Institute of Psychiatry and was a special Aubrey Lewis Memorial Meeting at which many eminent speakers paid tribute to the work of Sir Aubrey. The Fiftieth Maudsley Lecture, 'The Making and Breaking of Affectional Bonds' was delivered by Dr John Bowlby. The Maudsley Lecturer in 1977 will be Professor Kathleen Jones. In February 1977 the Blake Marsh Lecture was delivered by Professor A. N. Davison, entitled 'Biochemistry of Brain Development and Mental Retardation'. The Spring Quarterly Meeting was held at Craig Dunain Hospital and Craig Phadrig Hospital, Inverness; the College's gratitude and thanks for a most happy and successful meeting are due particularly to Dr Martin Whittet and all his staff and to those who gave generously of hospitality to the College. Full details of the meetings are contained in the Minutes which are published in News and Notes.

The Research Committee (Ghairman: Dr B. Barraclough) learned with regret that the Medical Research Council was not willing to finance the proposed psychosurgery research project on the grounds that the College was unable to meet its scientific requirements; the Committee is, however, currently conducting a postal survey of neurosurgical units, and in November members of the Research Committee met representatives of the DHSS to discuss matters relating to psychosurgery. The results of the survey of a random sample of College members to obtain information on the use of barbiturates, conducted in co-operation with GURB (The Campaign on the Use and Restriction of Barbiturates), has been published in the B.M.F. (16th October 1976). The Research Register, maintained by Dr R. Maggs and held at Hellingly Hospital, is for the use of members wishing to contact others with similar interests, and is also intended to help trainees wishing to identify workers with whom they may be able to discuss their interests.

Dr Edward Hare has continued to guide the British Journal of Psychiatry and the Journal Committee with great expertise, wisdom and skill, and the Journal maintains its reputation as the foremost psychiatric journal; its income makes a valuable contribution to the work of the College. In the interests of economy certain modifications have been made in the methods of production. News and Notes, under the editorship of Dr T. A. Kerr, reports fully on College matters and other items of interest, and its wider distribution is under discussion; from July 1977 the title of the supplement has been changed to The Bulletin of the Royal College of Psychiatrists. The Associate Editors are Sir Martin Roth and Dr A. Walk; the Assistant Editors are Dr Brian Barraclough, Dr T. A. Kerr, Dr R. Mayou and Dr Philip Snaith.

Following the report of the surplus on the Annual Accounts for 1976, Council has approved the reinstallation of the Library in its new home at 17 Belgrave Square. This involves considerable work on the strengthening of the floor of the room allocated to house the Library and also electrical re-wiring, and it is unlikely that this will be completed before the autumn. In the meantime, Dr H. R. Rollin, the Librarian, and the Library Committee are making plans for the new Library; in the first instance the books will be taken out of store and temporarily housed in the basement during sorting. The purpose, 
scope and remit of the Library are currently under consideration. It is hoped that the New Year will see the opening of the new Library.

\section{The Court of Electors}

The following are the results of the Membership Examinations and the Preliminary Test since the inception of the College:

Membership Examination

\begin{tabular}{|c|c|c|c|}
\hline Date & & Sat & Passed \\
\hline March $1972 \ldots$ & . & 323 & 228 \\
\hline November 1972 & . & 432 & 306 \\
\hline May 1973 . . & . & 445 & 304 \\
\hline November 1973 & .. & 215 & 129 \\
\hline May $1974 \quad \ldots$ & .. & 194 & 113 \\
\hline November 1974 & . & 180 & 100 \\
\hline May $1975 \quad$. & . & 169 & 90 \\
\hline October 1975 & .. & 192 & 107 \\
\hline May $1976 \quad \ldots$ & .. & 219 & 129 \\
\hline October 1976 & .. & 208 & 118 \\
\hline May $1977 \quad \ldots$ & .. & $\mathbf{n} / \mathbf{a}$ & $\mathbf{n} / \mathbf{a}$ \\
\hline
\end{tabular}

Preliminary Test

\begin{tabular}{llcc}
\hline \multicolumn{1}{c}{ Date } & & Sat & Passed \\
\hline November 1971 & $\ldots$ & 10 & 5 \\
March 1972 .. & $\ldots$ & 13 & 9 \\
October 1972 & $\ldots$ & 47 & 32 \\
March 1973 .. & $\ldots$ & 87 & 58 \\
September 1973 & $\ldots$ & 181 & 107 \\
March 1974 .. & $\ldots$ & 201 & 94 \\
September 1974 & $\ldots$ & 243 & 104 \\
March 1975 . & $\ldots$ & 307 & 119 \\
September 1975 & $\ldots$ & 299 & 123 \\
March 1976 . & $\ldots$ & 330 & 138 \\
September 1976 &.. & 296 & 140 \\
March 1977 .. &.. & 392 & 170 \\
\hline
\end{tabular}

Further information is being obtained from the computer analysis of the examinations, but this has been held up by industrial action. In the meantime an interim report has been submitted to the Court of Electors on the research being undertaken into the use of videotapes in psychiatric examinations. A further meeting of Examiners and an Examinations Forum provided opportunities for very wide-ranging discussions of many aspects of the examinations amongst all those concerned, and the examinations have continued to evolve and have been modified as a result of these exchanges; certain alterations have been made to encourage candidates wishing to take advantage of the Research Option, and there have been changes in the format of the clinical part of the Membership. The Chief Examiner, Professor J. L. Gibbons, is visiting the USA and Canada to study various examinations techniques.

The first series of Approval visits to hospitals providing training for the M.R.C.Psych. has been completed. Some 237 hospitals have been visited and a great deal of work has been done by the Dean, the Conveners and the members of the Panels of Visitors. This is one of the most important tasks undertaken by the College, because standards of training and patient care are thereby improved. Hospitals which were originally given Provisional Approval (P or PS) are being re-visited, as are hospitals which were not approved if they consider that their deficiencies have been remedied. The Conveners of Panels, who have carried a great burden of work and to whom the College's gratitude is due, are: Scottish Division, Dr J. K. Binns (1974-77), Dr W. E. S. Kiernan; Irish Division, Prof T. J. Fahy; Welsh Division, Dr M. W. Annear; North East Division: Dr K. Davison (1974-76), Dr I. R. Card; North West Division: Dr M. D. Cashman; Midland Division: Dr K. Myers; South Western Division: Dr J. S. Grimshaw (1974-77), Dr D. H. Dick; Chiltern and Thames Valley Division: Dr F. J. J. Letemendia (1974), Dr B. L. Mallett (1975-77), Dr A. M. Gordon; East Anglian Division: Dr A. R. K. Mitchell (1974-76), Dr G. J. Goldberg; Southern Division: Dr M. S. Perinpanayagam.

The current membership numbers are as follows:

$$
\begin{aligned}
& \text { Honorary Fellows } \quad \text {. } \quad \ldots \quad 5 \text { 5 } \\
& \begin{array}{llllll}
\text { Fellows } & . & \ldots & \ldots & \ldots & 5 \\
& & & &
\end{array} \\
& \text { Members .. } \quad \text {.. } \quad \ldots \quad \ldots \quad \text {.. } 3,562
\end{aligned}
$$

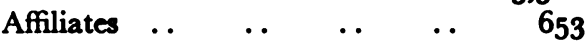

$$
\begin{aligned}
& \begin{array}{llllll}
\text { Inceptors } & \because & \ldots & \ldots & \ldots & 462
\end{array} \\
& \text { Corresponding Fellows .. .. } 45 \\
& \text { Corresponding Associates } \quad \text {.. } \quad 77 \\
& 5,746
\end{aligned}
$$

\section{Linson with OTHen Bodres}

The College is represented on many of the most important inter-professional medical committees by the President, Professor Linford Rees, who reports on the activities of these bodies, including the Joint Consultants Committee, the Standing Medical Advisory Committee, the Central Health Services Council, the Council for Postgraduate Medical Education, and the Conference of Presidents of 
Medical Colleges and Faculties. Other members represent the College on many other committees and professional bodies. There are Joint Committees with the Royal College of Physicians and the Royal College of General Practitioners, with the British Paediatric Association, the British Psychological Society, the British Geriatric Society and the BMA.

There are regular meetings with the DHSS to discuss manpower topics, and there is an annual meeting which considers any other relevant matters of concern or interest to the Department or the College. The College has nominated representatives to serve on the inter-disciplinary Working Groups being set up by the DHSS to consider Regional Secure Units and the Organisational and Management Problems of Mental Illness Hospitals; discussions are also proceeding about the Department's proposals to conduct a Survey of Patients Discharged from Mental Illness Hospitals to the Community. Guidelines on the Care and Treatment of Mentally Disturbed Offenders prepared jointly by the College and DHSS have been approved and published (News and Notes, April 1977).

Following the publication of the Memorandum on Confidentiality (News and Notes, January 1977) it is hoped to set up a multi-disciplinary committee, with representatives of other interested parties, including the Royal College of Nursing, MNND, the Patients' Association, social workers and records officers, to inquire into problems of security, access to, and confidentiality of, psychiatric case records. Dr Brian Ward represented the College at a workshop on Confidentiality organised by MIND.

The work of the Joint Committee on Higher Psychiatric Training (Royal College of Psychiatrists and Association of University Teachers of Psychiatry) continues. All trainees in higher training are being asked to complete a questionnaire as a preliminary to enrolment; in the meantime the Joint Committee is approving posts and programmes for higher training. The College and the Association are urgently discussing the need for the accreditation of trainees at the end of Higher Psychiatric Training; the Joint Committee is responsible for making recommendations to the General Medical Council in connection with EEC Specialist Registration.

\section{The Divisions}

The Scottish, Irish and Welsh Divisions continue to liaise directly with their national Departments as well as to play an important part in the composite life of the College. Many of the Divisions have organised Dinners, sometimes in conjunction with ceremonies to welcome new Fellows and Members, and often the President has been present on these occasions. The Scottish Division was pleased to welcome the College to Inverness for a Quarterly Meeting, and it is hoped to visit Ireland next year. The Officers of the Divisions are:

Scottish-Ghairman: Dr A. C. Tait; Secretary: Dr G. G. Timbury.

Irish-Ghairman: Dr S. D. McGrath; Secretary: Dr K. Sinanan.

Welsh-Ghairman: Dr T. Gwynne Williams; Secretary: Dr J. M. Cuthill.

East Anglian-Vacancy for Chairman; Secretary: Dr A. C. Kaeser.

Chiltern and Thames Valley-Chairman: Dr J. Candy; Secretary: Dr D. Dickens.

Midland-Chairman: Dr T. L. Dunn; Secretary: Dr E. B. Gordon.

North East-Chairman: Dr J. M. Roberts; Secretary: Dr D. A. Stephens.

North West-Chairman: Dr P. Harper; Secretary: Dr D. A. W. Johnson.

Southern-Ghairman: Dr R. Maggs; Secretary: Dr E. D. West.

South Western-Chairman: Dr D. F. Early; Secretary: Dr C. Davies.

\section{Specialist Sections and Groups}

The Specialist Sections have continued to play an important part in the life of the College through their representation on the Standing and Special Committees and Council and through the influence of various 'sub-sections' within some Divisions, as well as directly by submissions to the Council, and through independent scientific and social events.

The Psychotherapy Section (Chairman: Dr R. Gosling; Secretary: Dr P. O'Farrell) has held regular scientific meetings and meetings of the Executive Committee throughout the year. The speakers at the scientific meetings have included Dr B. Dick (The Facilitation and Nature of Patient Change through Group Analytic Psychotherapy); Dr P. L. G. Gallway (Transference Utilization in Aim-Restricted Psychotherapy-Some Technical Considerations); Dr J. L. Wilson (Some Reflections on 'Action' and 'Encounter' Techniques in Relation to the Practice of Psychotherapy); Dr R. Gosling (Chairman's AddressAnother Source of Conservatism in Groups); Dr B. Mandelbrote (The Isis Centre-A Counselling Service within the NHS); Dr N. Yorkston (Psychotherapy versus Behaviour Therapy-A Comparative Study Carried Out at Temple University, Philadelphia); Mrs Clare Winnicott (A Clinical Example of D. W. Winnicott's Paper Fear of Breakdown); Dr Murray Cox (Group Psychotherapy, the Psychopath 
and the Total Insitutition-A Vicious or a Magic Circle); Dr E. A. M. Wood (Consultation in an Institution on the Development of a Special Unit); Professor W. H. Gillespie (The Place of Psychoanalysis in Psychotherapy). Matters discussed by the Executive Committee have included the possibility of arranging series of lectures outside London and groups for Registrars in London; the content of the Reading List; the DHSS manpower statistics in relation to psychotherapy posts, and the description, distribution and availability of these posts, and also matters concerning psychotherapy manpower in Scotland; the statutory registration of psychotherapists; the work of the JCHPT; the new Joint Committee with the British Psychological Society; the Royal Commission on the National Health Service; and evidence to the Home Office Working Party on Marriage Guidance. The Section has also submitted possible draft questions for the MCQ and essay papers of the Membership Examination and the Preliminary Test. Dr I. S. Kreeger represents the Section on the Manpower Sub-Committee and at the DHSS manpower meetings and at the inter-disciplinary discussions being held on the statutory registration of psychotherapists.

The Forensic Psychiatry Section (Chairman: Dr Peter Scott; Secretary: Dr R. S. Bluglass) has members on Council and the Standing Committees and has been represented on many of the Special Committees which have prepared evidence for official bodies, including the Review of the Mental Health Act, the Care and Treatment of Mentally Abnormal Offenders, the Royal Commission on the NHS and Alcoholism. The Section has nominated College representatives to serve on the inter-disciplinary Working Group on Regional Secure Units, and is concerned that although this was envisaged many months ago it has not started its work although finance has apparently been allocated for this purpose; in the meantime a Section meeting on the day preceding the Annual Meeting is being arranged on the subject.

A residential Conference on forensic psychiatry nursing is being arranged jointly with the Royal College of Nursing. Other matters discussed by the Executive Committee have included the work of the Forensic Psychiatry Specialist Advisory Sub-Committee of the JCHPT; the joint committee with the Prison Medical Service; the Home Office Panel of Senior Psychiatrists. Comments on the Home Office Working Party Report on Judicial Training and Information and a reply to a request from the Campaign for Homosexual Equality were drafted by the Chairman and adopted by the College.
The Mental Deficiency Section (Ghairman: Dr Valerie Cowie; Secretary: Dr W. R. McKibben) has organized meetings at Turner Village Hospital, Colchester, and at St Lawrence's Hospital, Caterham, and in each case its members are most grateful for the welcome extended to them. In December the Section held a most enjoyable and successful Dinner in London. The Section has been much involved with the Special Committee, under the Chairmanship of the President, which was set up following the statement presented to the Council in June 1976; this Committee has met on several occasions and it hopes to present its report and recommendations before the end of the year. The Section, through its representatives, has been involved in the work of the Standing Committees, the Council and its Special Committees, including the Review of the Mental Health Act, the Care and Treatment of Mentally Abnormal Offenders, the Royal Commission on the NHS, and the Responsibilities of Consultants in Psychiatry within the National Health Service. The Executive Committee has extended what help it could to the member who is now involved in an official Inquiry. The Executive Committee has also considered joint appointments with other specialties, the membership of Committees of Inquiry, mental handicap nursing and care, inter-disciplinary relationships, higher training requirements, dental care, the Report of the Committee on Child Health Services, and the circulation to members of the Section of a questionnaire to ascertain their feelings about the future of mental deficiency.

The Child Psychiatry Section (Ghairman: Professor P. J. Graham; Secretary: Dr I. Berg) has prepared evidence for the Joint Working Party on Pregnant Schoolgirls and Schoolgirl Mothers (Newes and Notes, March 1977); and is currently preparing a memorandum on that part of the Report of the Committee on Child Health Services relevant to the Section. Other matters discussed by the Executive Committee have included child psychiatrists transferred from Local Authorities; the future of Inter-Glinic Conferences; the role of Child Psychiatrists in the community, the attachment of child psychiatrists to a hospital base; an annual Lecture in Child Psychiatry; and the submission of draft questions for the Membership Examination. The annual residential weekend, at which a wide variety of topics were discussed, was held at St Catherine's College, Oxford, and was very successful and well attended. A one-day conference on 'The First Year of Life: its significance for later social development' was held at the Royal Society of Medicine. The Section is represented on many 
College committees and through its representatives has exerted considerable influence upon the work of the College. Among the Special Committees whose work has been of particular interest are those on the Role of Psychologists in the Health Service (Trethowan); the (Court) Committee on Child Health Services; the Royal Commission on the NHS and Violence in the Family.

The Group for the Psychiatry of Old Age (Chairman: Dr Felix Post; Secretary: Dr Brice Pitt) has met regularly throughout the year and has helped in organizing scientific sessions at College meetings. It has also participated in the work of the Joint Committee with the British Geriatric Society, with whom a memorandum on Mental Health in Old Age was jointly prepared. Topics discussed by the Group include the DHSS document on Residential Homes for the Elderly (Newes and Notes, September 1976); psychogeriatricians; minimum standards of staffing; specialized homes for the elderly mentally infirm; hospital in-patient accommodation for patients with dementia. The Group was also grateful to Dr Woodford-Williams, Director of the Health Advisory Service, for attending the meeting at which the work of the Service was discussed and for describing its activities and difficulties.

The Social and Community Psychiatry Group (Chairman: Professor J. K. Wing; Secretary: Dr H. L. Freeman) has helped with the organization of College scientific meetings and through its Working Parties has considered a number of matters, including the possibility of organizing a conference on the use of volunteers (Preventive Psychiatry Working Party); the use of hospital beds and DGH units (Services Working Party); the future of the Group, and a possible business meeting. The Services Working Party organized a very successful seminar at the CIBA Foundation in February 1977, and the Group is contributing towards one of the sessions at the forthcoming Annual Meeting of the College.

\section{College Headquarters}

Reference has already been made to the re-installation of the Library and a further phase in the rewiring of 17 Belgrave Square. Other major alterations - the Lecture Theatre on the ground floor and meeting rooms and a buffet in the basement-must wait until funds are available, but minor changes and improvements are gradually taking place. A gas oven has been installed in the space where there will be a kitchen when the basement is developed and a partition is being put up on the ground floor in connection with the new mini-computer which should be in working order in August and which will make for smoother and more efficient working and management of College business. The house has been enhanced by generous gifts from people too numerous to list, and further furniture for the President's room is being bought with money donated specifically for that purpose.

\section{Thanks}

There are always many people to whom the College is indebted, and among this number are the Officers of the College. This year particular mention must be made of the Dean, Professor Ken Rawnsley, who is retiring and who, during the formative years of the College, has set high standards of dedication, skill and tact as the Officer responsible for the Examination, the Approvals Visits and Research, and also as Chairman of the Education Committee and the Programmes and Meetings Committee. Professor Rawnsley has been ably supported by Sub-Deans, two of whom retire this year. Dr A. Shapiro has spent much time attending the examinations, comparing standards and bringing back to the Examinations Sub-Committee much invaluable information and comment. Dr T. H. Bewley has been Secretary of the Education Committee, which is so much concerned with the work for which the Dean is responsible; he has also, as Secretary and later Chairman of the Manpower Sub-Committee, helped to guide the College through its discussions with the DHSS and others. Dr Edward Hare's Editorship of the British Fournal of Psychiatry has been marked by his skill, knowledge, efficiency and his purposeful attention not only to high academic standards but also to details of finance and production, which has enabled the profitability of the Journal to help the College through some very difficult times. To the retiring Officers and to those Officers who will continue in 1977-1978, to the Registrar, Dr Morris Markowe; the Treasurer, Dr Wilfrid Warren; the Librarian, Dr H. R. Rollin and Sub-Dean, Dr Peter Brook, Members' thanks are due for their untiring efforts and vigilance, as they are also to the President, Professor W. Linford Rees, who has continued to guide our affairs with great kindness, skill and leadership during a further very busy year.

Many, many people help with the work of the College and give generously of their time, effort, expertise and funds, thus helping our patients and all our members. These helpers include the Chairmen and Secretaries of all Committees, Sections and Divisions, as well as Assessors, Examiners, Visitors, trainees and tutors. Outstanding among the many 
who have merited a 'thank-you' stands our secretariat so ably led by Natalie Cobbing, our Secretary; always ready to help, always available, and always constructive. It is on this note of gratitude and appreciation that we look forward to the next College year with confidence.

\section{Supplementary Report}

The Registrar, Dr MARkows, introduced the Report and read the following Supplementary Report of events since the Annual Report had been printed:

The recent ballots have resulted in the election of the following Officers who will take office today:

$\begin{array}{ll}\text { Dean } & \text { Dr T. H. Bewley } \\ \text { Editor } & \text { Dr J. L. Grammer } \\ \text { Sub-Deans } & \text { Dr C. P. B. Brook } \\ & \text { Dr S. B. Mahapatra } \\ & \text { Dr E. B. O. Smith }\end{array}$

These results, and those for elected members of Council and the Court of Electors have only just become available; details will be published in the Bulletin of the College.

Since the Annual Report was sent to the printers representatives of the College have had informal discussions with representatives of the Privy Council who have made a number of very helpful and hopeful suggestions about the proposed alterations in the Bye-laws. A few minor changes in the proposals will be submitted to a General Meeting of the College before formal submission to the Privy Council, who in the meantime are consulting various bodies.

We have also had discussions with the DHSS. The annual meeting at the Department discussed a variety of topics, including consultant responsibility, the relationship between Health and Social Services, the Health Advisory Service, Buildings, Committees of Inquiry and 'Three Wise Men' procedures, and problems relating to assessment units in relation to the psychiatry of old age. The proposed survey of patients discharged from mental hospitals into the community, was also discussed, and it was agreed that this should be endorsed by the College, following assurances about the way in which the survey was to be carried out, and aspects of confidentiality.

Arising from the Committee of Inquiry into events at Normansfield Hospital, the Special Committee which is considering ways in which sick doctors may be helped and their interests and those of their patients protected, has been asked also to review 'Three Wise Men' procedures and to make recommendations to Council.

Professor KETY, now shortly to be elected as an Honorary Fellow, has agreed to deliver the Maudsley
Lecture in 1978, and Dr Grorge TARJAN has been invited to give the Blake Marsh Lecture.

At its meeting this Friday the Executive and Finance Committee will be considering a request from the Department of Education and Science for evidence on Corporal Punishment; at very short notice a Special Committee with representatives from the Forensic and Child Psychiatry Sections is drawing up recommendations. The Executive and Finance Committee will also be considering a request from the Criminal Law Revision Committee for comments on their working paper on Offences against the Person, with special reference to mercy killing; and a proposed DHSS circular on 'Children in Hospital-Maintenance of Family Links' on which the advice of the Child Psychiatry and Mental Deficiency Sections will be available.

The Executive and Finance Committee will also be considering a letter which it is proposed to send to our members to see whether there would be support for setting up a Group and later a Section, for Biological Psychiatry.

Finally, members will be interested to know that if all continues to go according to schedule our new mini-computer will be installed at the beginning of August; in the meantime records are being put on discs and will be ready for use as soon as the machine is available. The response to the questionnaire sent to members has been good, but a reminder is being sent to those members who did not return the form. The first phase of the operation covers the general records; subscription records will be put on to the computer during the second phase, from August to December this year, and it is hoped that with the opening of the new financial year the new system will be fully operative. We hope that, after the inevitable teething problems the College recording systems will run more smoothly and more easily for our staff.

The new Membership List will be sent to members at the end of this month. There has had to be a lapse of time between the preparation of the List and its printing and publication and it has not been possible to take account of the many alterations that will have come to light on the computer questionnaires. It is hoped that a second and updated List will be published next year.

\section{The Annual Report was approved.}

\section{Thanks to Retiring Officers}

Professor Sir Martin Roth proposed a vote of thanks to the retiring Dean, Professor Ken Rawnsley, and to the retiring Sub-Deans, Dr A. Shapiro and Dr T. H. Bewley, all of whom had rendered excep- 
tional service to the College during its formative years. Dr Bewley had been active in many spheres, particularly on the Education Committee and its sub-committees, and Dr Shapiro had been a staunch worker on Council and in the interests of Mental Deficienı y; the Sub-Deans had been a great support to the President. In the early, difficult days of the examination and in setting up the College programme of inspecting hospitals Professor Rawnsley, as first Dean of the College had rendered the College outstanding service, always thorough, fair-minded, and supportive, however many the calls upon his time.

Dr Alexander Walk proposed the vote of thanks to the retiring Editor, Dr E. H. Hare. He referred to Dr Hare's comprehensive grasp of the Journal's affairs and the very high scholarly and literary standards achieved and maintained during his editorship, a time also marked by a financial success unprecedented and due to Dr Hare's interest in this part of the work. Dr Hare's Associate and Assistant Editors were grateful to him for the help, advice and encouragement he had always given them.

The votes of thanks were carried by acclamation.

Dr T. H. Bewley was welcomed as the new Dean, and Dr J. L. Grammer as the new Editor. The new Sub-Deans, Dr S. B. Mahapatra and Dr E. B. O. Smith were also welcomed.

Annual Report of the Treasurer and Accounts

\section{Accounts}

The accounts for the year to $3^{1}$ December 1976 are presented on pages 87 to 91 and cover the College's second year at 17 Belgrave Square. They show a building up and consolidation of the financial state of the College. The dominant features of the balance sheet are again the cost of the College Headquarters and the amount still outstanding on the loan from Guiness Mahon and Co. Ltd. Unremitting efforts have continued to raise further capital to pay off this loan and then to open up and make fuller use of these premises for the College Headquarters. These efforts will need to contue in future years.

The financial position of the College has strengthened compared with that at the end of 1975 . Income from subscriptions and fees almost doubled to f157,283 ( $f 87,234)$. There was little expenditure during the year towards refurbishing the property. No further money from the General Fund was used to reduce the loan. Thus, as indicated in the 'Statement of Source and Application of Funds' on page
90, the liquid funds of the College rose by $£ 59,175$ compared with the situation in 1975 .

Provision for the normal running costs of the College is thus greatly strengthened. Instead of the deficit of $£_{29}$ that occurred in 1975 , a surplus of $£ 27,061$ has been made. This was to be expected after the rise in subscription rate from I January 1976; but such a surplus is likely to lessen each succeeding year with continuing inflation. However, the surplus reflects the considerable care taken by College staff during the year to keep down running costs. 'Note 1, Establishment and Administration Expenses', page 89 shows the rises in costs that occurred especially in printing; the expected steep increase in the cost of postage and telephones did not occur. The grant from the Department of Health and Social Security towards expenses arising from the assessment of general professional training rose to $£ 8,546$ ( $£ 7,289$ ). The publications operations of the College, including The British Journal of Psychiatry, Schedule III (page 88) had a particularly satisfactory year with a surplus of $£_{31,852}(£ 6,575)$, after writing off the cost of journals distributed to members. Here again great care was taken to keep the cost of production from rising.

The Examination Account (page 89 Note 3) showed a deficit of $£ 4,608$. $£ 3,184$ of this was due to expenditure on research on the Examination earlier arranged; the cost of running the Membership Examination continued to rise.

The market value of Investments at the end of 1976 was $£_{146,601}$ compared with $£_{128,504}$ at the end of the previous year.

\section{Appeal Fund}

During 1976 a further $f_{176,917}$ was subscribed to the Appeal Fund; $£ 164,668$ by generous benefactors from outside the College and $f_{12,249}$ from members. The debt of Guinness Mahon stood at $£ 289,607$ at the end of 1976 ( $£ 428,405$ at the end of 1975). This improved net repayment of $£_{138,798}$ was achieved despite a further interest charge for the year of $£ 44,660$ which was paid out of the Fund. Thus, whilst progress was made, the large interest charge on the loan has still been a considerable handicap to the College. Further urgent steps are being taken in 1977 to try to pay off the loan, including the switch of the loan from Guinness Mahon to Barclays Bank to the College's advantage.

This has been a satisfactory year financially for the College, in spite of the continuing national recession and accompanying vicissitudes. Apart from the further progress made with the Appeal to gain capital, the rise in subscriptions has led to this much 
strengthened situation. Prudence exercised in keeping down expenditure should be noted; many have helped to bring all this about and thanks are due to them. As a result, the College has, early in 1977, been able to pay Guinness Mahon another $£ 50,000$ from General Funds, in anticipation of further donations from outside. A mini-computer costing about $£ 28,000$ has been ordered, and when this is operating should greatly enhance the efficiency of administering College affairs. Plans are afoot in 1977 to install the College Library, which has been in store for two years, in its new home.

The Treasurer, Dr Wilfrid WarRen presented the Report and Accounts.

Approval of the Report and Accounts was proposed by Dr W. A. Heaton-Ward, seconded by Dr R. W. Simpson and carried nem con.

\section{Auditors}

Messrs Turquands Barton Mayhew and Co were reappointed as the College's Auditors for 1977-78.

\section{Medals and Prizes}

The Gaskell Medal and Prize were presented to Dr J. C. Cutring, The Maudsley Hospital, and the Bronze Medal and Prize was presented to Dr P. Bebrington, M.R.C. Social Psychiatry Unit, Institute of Psychiatry.

\section{Overseas Delegates}

Representatives of overseas Colleges and Associations were presented to the President and welcomed to the meeting:

Dr A. Ellis, Immediate Past President of the Royal Australian and New Zealand College of Psychiatrists; Dr J. Nehil, Treasurer/Archivist, Societé MedicoPsychologique; Dr Tarig Sohail, the Treasurer/ Secretary of the Pakistan Psychiatric Society was delayed, but presented to the President at the Annual Dinner; Dr William Sargant represented the Canadian Psychiatric Association; Dr Jose Delgado, Spain.

The President also welcomed many other overseas members and guests who were attending the meeting. There were visitors from Australia, Canada, South Africa, Germany, Norway and the USA.

\section{Election of Honorary Fellows}

The following were unanimously elected to Honorary Fellowship:

Dr Seyrour Kety, McLean Hospital, Massachussetts.
Professor Ørnulv ØdegRrd, Oslo. The Rt Hon LoRd Rayne.

Professor K. Rawnsley, Cardiff. Sir Henry Yellowlezs.

The new Honorary Fellows were introduced and, with the exception of Dr Seymour Kety who had been unable to be present, were presented to the President.

Dr D. Richter introduced Dr Seymour Kety to the College; Dr Kety was renowned as a neurochemist as well as for his biological approach to psychiatry and his works were already the classics of the subject. It was hoped that he would be one of the most enthusiastic members of the proposed Group for Biological Psychiatry.

Dr P. Sainsbury introduced Dr ØrNuLv $\emptyset_{D E G} \AA_{R D}$ and welcomed him to the meeting. Dr Ødegard's epidemiological work and social and environmental studies had been well known and admired for five decades and would continue to be an inspiration to future generations.

Dr W. Warren welcomed LoRd RAYNe to the meeting and expressed the College's thanks to him for the help and wise advice he had given personally towards establishing the College in its new headquarters and keeping the College's finances on a sound footing. Moreover the Rayne Foundation's generous donations to the Appeal had made a great difference to the College's financial stability. Lord Rayne was a busy man with many interests but his advice had always been willingly, kindly and firmly available and most gratefully received.

Dr John Hamilton welcomed Professor KEN RAwNSLEY to the Honorary Fellowship, an award given in recognition for his work in psychiatry, but particularly his work as the first Dean of the Royal College of Psychiatrists. He was well known to all for his willingness to help, his wisdom, patience and fairmindedness, and it was hoped that he would continue to serve the College. In particular Professor Rawnsley had been most concerned with standards of training and the College programme of inspection of training hospitals; the effects of this exercise were already being felt and ultimately this must improve the standard of patient care.

Dr M. Markowe expressed the College's delight at the election of Sir Henry Yenlowlers, Chief Medical Officer at the DHSS, to Honorary Fellowship. Sir Henry had had a distinguished career as well as a distinguished psychiatric family background. Sir Henry's meteoric medical career had been marked by diligence, thoroughness and a flair for administration, and perhaps to some extent his ability to 
deal with his fellow men could be attributed to his poychiatric forebears.

\section{Social Events}

The Annual Dinner was held in the Great Hall of St Bartholomew's Hospital on Wednesday, 6 July. Dr W. A. Heaton-Ward proposed the toast of 'The Guests' and Sir John Richardson replied. The Toast of 'The Royal College of Psychiatrists' was proposed by the Rt Hon David Ennals, M.P., Secretary of State for the Social Services, and the President replied.

On Tuesday, 5 July, over two hundred members and guests attended a Reception at the Royal College of Psychiatrists.

Members' wives and husbands were accompanied by Mrs Linford Rees at a performance by the Royal Ballet on Wednesday $6 \mathrm{July}$, and on a visit to the Silver Vaults, Chancery Lane, on Thursday, 7 July.

\section{ELEGTION OF FELLOWS}

The following Members have been elected to the Fellowship:

E. Anthony, D. M. Bassa, J. S. Bearcroft, A. W. Beard, I. S. Berg, Dorothy Bicknell, B. Blackwell, S. Bockner, A. C. Brown, D. G. Brown, J. Buckman, J. R. M. Copeland, J. A. Corbett, F. M. S. Dabbagh, R. J. Daly, H. A. Darwish, G. I. Davies, K. A. Day, S. R. Dean, P. T. d'Orban, H. B. Durost, Elizabeth Easton, D. Eccleston, J. P. Farrell, M. M. Feldman, J. J. Fennelly, H. C. Ferguson, K. M. Fraser, D. E. Friedman, M. Glasser, M. D. A. Heller, G. F. D.
Hesseltine, D. C. James, P. F. Johnson, K. Jones, Muriel Jones, A. C. Kaeser, N. J. Kothari, L. C. Kreeger, G. A. Levinson, C. J. Lucas, E. G. Lucas, N. Lukianowicz, D. J. McClure, W. R. McLeod, S. B. Mahapatra, F. M. M. Mai, G. Milner, J. H. Orr, J. R. Palmer, R. A. Parry, P. M. Ployé, L. B. Raschka, O. R. Schmalzbach, G. Sedman, H. G. S. Sergeant, H. Stewart, E. Stonehill, H. R. Suliman, F. G. Thorpe, J. E. Varley, V. K. Varma, D. A. Walk, C. J. Wardle, H. C. White, R. W. Whiteley, E. A. M. Wood, W. B. Wright and A. Zarrabi.

\section{PHOTOCOPIES OF ARTICLES IN 'THE READING LIST IN PSYGHIATRY'}

The reference on page $I$ of this List to 'those contemplating ordering photocopies' means ordering through the Librarian of a medical or psychiatric library who has access to a range of journals and books either through their own collection or the British Library at Boston Spa. Neither Headley Brothers Ltd nor The Royal College of Psychiatrists can supply these photocopies. 